\title{
How can undergraduate ophthalmology teaching be improved?
}

This article was published in the following Dove Press journal:

Advances in Medical Education and Practice

25 June 2015

Number of times this article has been viewed

\author{
Elliott Yann Ah-kee' \\ Aamir Asif Khan ${ }^{2}$ \\ 'Department of Surgery, Monklands \\ Hospital, Monkscourt Ave, Airdrie, \\ North Lanarkshire, ${ }^{2}$ Glasgow Royal \\ Infirmary, Glasgow, UK
}

\section{Dear editor,}

We read with high interest the article by Shah, ${ }^{1}$ which describes strategies for curriculum changes to increase exposure to smaller specialties, including dermatology, psychiatry, and radiology. To this list of specialties, we would also like to add ophthalmology. In a survey of UK medical schools, Baylis et al ${ }^{2}$ found that undergraduate ophthalmology attachments were not compulsory and sometimes only limited to 7 days. Moreover, medical schools were gradually reducing the amount of exposure to ophthalmology within the curriculum.

In the article, the author points out the shortfall of psychiatrists and interventional radiologists in the UK and USA due to the lack of exposure in medical school. In contrast, ophthalmology remains extremely competitive with relatively few training posts available. However, in the UK, for instance, lack of undergraduate ophthalmology education has resulted in many new medical graduates lacking basic ophthalmic skills which are required for foundation years, and this particularly affects those who will work in the accident and emergency department. A recent 2008 survey in England by Sim et $\mathrm{al}^{3}$ showed that $63.9 \%$ of senior house officers have little or no confidence in dealing with eye emergencies, and this proportion is unchanged from a previous similar national survey by Tan et al. ${ }^{4}$ This can potentially lead junior doctors missing important ocular signs that can subsequently have devastating sight-threatening or life-threatening implications.

The author also highlights different strategies adopted by the Royal College of Psychiatrists to address the shortage of psychiatrists, including setting up medical school societies, career fairs, summer schools, intercalated Bachelor of Science programs, and student elective modules to enhance students' learning. While we believe that similar measures can be employed to improve ophthalmology teaching and learning outcomes, we would also like to highlight the emergence of e-learning and its positive impact on the delivery of medical education. In a survey of undergraduate medical students, Gormley et $\mathrm{al}^{5}$ found that the use of e-learning was rated just as highly as other traditional methods of teaching and recommended its use in a blended approach.

Succar et $\mathrm{al}^{6}$ reported the success of an interactive web-based teaching module, the Virtual Ophthalmology Clinic, based on statistically significant improvement in academic performance and highly positive student feedback. Computer-assisted learning programs provide independence and flexibility, such that students are able to learn in their own time in off-site locations, while receiving online feedback from
Correspondence: Elliott Yann Ah-kee Department of Surgery, Monklands Hospital, Monkscourt Ave, Airdrie, North Lanarkshire ML6 0JS, UK Email elliottahkee@gmail.com submit your manuscript | www.dovepress.com

Dovepress

http://dx.doi.org// 0.2| 47/AMEP.S87654
Advances in Medical Education and Practice 2015:6 469-470

(c) (i) (5) 2015 Ah-kee and Khan. This work is published by Dove Medical Press Limited, and licensed under Creative Commons Attribution - Non Commercial (unported, v3.0) BY LC License. The full terms of the License are available at http://creativecommons.org/licenses/ly-nc/3.0/. Non-commercial uses of the work are permitted without any further permission from Dove Medical Press Limited, provided the work is properly attributed. Permissions beyond the scope of the License are administered by Dove Medical Press Limited. Information on
how to request permission may be found at: http://www.dovepress.com/permissions.php 
tutors. Furthermore, virtual simulation offers exposure to a wide variety of conditions.

Malik et $\mathrm{al}^{7}$ demonstrated the effectiveness of cataract surgery teaching videos to medical students by using the online questionnaires before and after viewing the videos as an assessment method. They noted a statistically significant mean percentage improvement in scores post-video. Additionally, the authors recommended the use of e-learning as an adjunct to support traditional teaching methods.

In conclusion, we would like to highlight the importance of an ophthalmology placement within the undergraduate medical syllabus. However, we also realize that this is not a straightforward issue due to the emphasis on core specialties and workforce requirements. Hence, we sought to draw attention to other methods such as the use of e-learning to improve ophthalmology teaching within an already crowded curriculum.

\section{Disclosure}

The authors declare no conflicts of interest in this work.

\section{References}

1. Shah S. Are curriculum changes the ideal method for increasing undergraduate exposure to tomorrow's specialities? Adv Med Educ Pract. 2015;6:153-154.

2. Baylis O, Murray PI, Dayan M. Undergraduate ophthalmology education - a survey of UK medical schools. Med Teach. 2011;33:468-471.

3. Sim D, Hussain A, Tebbal A, Daly S, Pringle E, Ionides A. National survey of the management of eye emergencies in the accident and emergency departments by senior house officers: 10 years on - has anything changed? Emerg Med J. 2008;25:76-77.

4. Tan MM, Driscoll PA, Marsden JE. Management if eye emergencies in the accident and emergency department by senior house officers: a national survey. J Accid Emerg Med. 1997;14(3):157-158.

5. Gormley GJ, Collins K, Boohan M, Bickle IC, Stevenson M. Is there a place for e-learning in clinical skills? A survey of undergraduate medical students' experiences and attitudes. Med Teach. 2009;31(1):e6-e12.

6. Succar T, Zebington G, Billson F, et al. The impact of the virtual ophthalmology clinic on medical students' learning: a randomised controlled trial. Eye (Lond). 2013;27(10):1151-1157.

7. Malik U, Kirkby E, Tah V, Bunce C, Okhravi N. Effectiveness and acceptability of a cataract surgery teaching video for medical students. Med Teach. 2012;34(2):178.

Dove Medical Press encourages responsible, free and frank academic debate. The content of the Advances in Medical Education and Practice 'letters to the editor' section does not necessarily represent the views of Dove Medical Press, its officers, agents, employees, related entities or the Advances in Medical Education and Practice editors. While all reasonable steps have been taken to confirm the content of each letter, Dove Medical Press accepts no liability in respect of the content of any letter, nor is it responsible for the content and accuracy of any letter to the editor.

\section{Publish your work in this journal}

Advances in Medical Education and Practice is an international, peerreviewed, open access journal that aims to present and publish research on Medical Education covering medical, dental, nursing and allied health care professional education. The journal covers undergraduate education, postgraduate training and continuing medical education including emerging trends and innovative models linking education, research, and health care services. The manuscript management system is completely online and includes a very quick and fair peer-review system. Visit http://www.dovepress.com/testimonials.php to read real quotes from published authors. 